\title{
Antibacterial activity and the histopathological study of crude extracts and isolated tecomine from Tecoma stans Bignoniaceae in Iraq
}

\author{
Amad M. Al-Azzawi, Ekbal Al-Khateeb', Kulood Al-Sameraei², Alyaa G. Al-Juboori ${ }^{3}$ \\ Ras Al Khaimah College of Pharmaceutical Sciences, Ras Al Khaimah Medical and Health Sciences University, Ras Al Khaimah, UAE, \\ ${ }^{1}$ Al-Ahliyya Amman University, Jordan, ${ }^{2}$ Biotechnology Research Center, Al-Nahrain University, Iraq, ${ }^{3}$ Department of General Education, \\ Ras Al Khaimah Medical and Health Sciences University, Ras Al Khaimah, UAE
}

Submitted: 14-06-2011

Revised: 02-08-2011

Published: 22-12-11

A B S T R A C T

Background: Tecoma stans (Bignoniaceae) is a central and south American tree used for the control of diabetes, also known as Yellow Elder, it was collected from the gardens of Al-Jadria in Iraq. Materials and Methods: One of the main reported alkaloidal constituents, tecomine, was isolated and confirmed by spectral analysis. The bacteriological assay for different plant leaves extracts; aqueous, ethanolic, and isolated tecomine were conducted to evaluate the antibacterial effect against gram-negative and gram-positive bacteria. Results: Whole alcoholic and aqueous extract exhibited the antibacterial activity and isolated tecomine. Histopathological evaluation was demonstrated on the liver, spleen, and pancreas of the BALB/c mice given the whole alcoholic and aqueous extract that showed no significant changes in the organ texture. Conclusion: Biochemical analysis of the serum obtained showed decrease in the glucose level in the mice treated with plant extract at the most two higher concentrations used with no change in the cholesterol and triglyceride level.

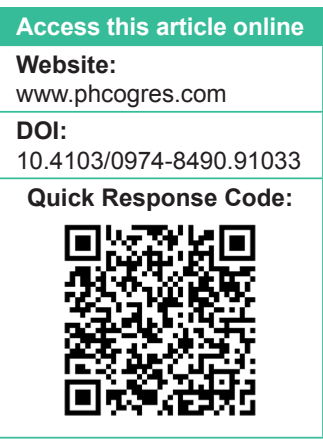

Key words: Antibacterial, histopathological, Tecoma stans, tecomine.

\section{INTRODUCTION}

Tecoma stans, is a common plant in Latin America, used traditionally in Mexico for the control of diabetes. The presence of alkaloids in T. stans was first reported in 1899, ${ }^{[1]}$ and the first alkaloid was isolated in 1959 by Hanrnouda and Motawi. ${ }^{\left[{ }^{[2]}\right.}$ The structure of tecomine was determined in 1962 by Jones et al., ${ }^{[3]}$ and a number of pyridine alkaloids of obvious monoterpene relationship have been isolated from the plant. ${ }^{[4]}$ Also in 1983, the indolic alkaloids were isolated from the leaves of T. stans. ${ }^{[5]}$ In 1993 , phytochemical investigation of an ethanolic extract from the fruits of $T$. stans has led to the isolation of two monoterpenic alkaloids, 7-hydroxyskytanthine, and 4-hydroxytecomanine. ${ }^{[6]}$ In 2003, Luca et al., isolated alkaloids and evaluated there in vivo and in vitro antidiabetic activity. ${ }^{[7]}$ Marzouk et al. identified a number of compounds

\section{Address for correspondence:}

Dr. Amad M. Al-Azzawi, RAK Medical and Health Sciences

University, College of Pharmaceutical Sciences, PO Box: 11172,

Ras Al Khaimah, United Arab Emirates.

E-mail: amadazzawi@yahoo.com from the fruits and flowers of the Tecoma that had antioxidant activity and anti-proliferative effect against cancer cell lines. ${ }^{[8]} \mathrm{A}$ study focuses on elucidating the pharmacological mechanism of T. stans antidiabetic effect of the aqueous extract on type- 2 diabetes mellitus animal models was due to intestinal alpha-glucosidase inhibition by decreasing the postprandial hyper-glycaemia peak. In addition, T. stans aqueous extract subchronic administration reduces triglycerides and cholesterol, without modifying fasting glucose..$^{[9]}$ Recently, Mathur et al., in 2010, stated that effects of $50 \%$ ethanolic extract of T. stans leaves in adult Wistar male rats on reproduction, where the effects may have an inhibitory influence on gonadotropin release that may be responsible for the decline in testosterone production, leading to changes in spermatogenesis. ${ }^{[10]}$ Senthilkumar et al. found that leaves have a potential broad spectrum antibacterial activity. ${ }^{[1]}$ The aim of this study is to investigate for the first time the antibacterial activity of aqueous, alcoholic crude extracts, and isolated tecomine from T. stans collected from Iraq. In addition, the histopathological evaluation of the liver, spleen, and pancreas of the BALB/C mice treated with whole crude aqueous and ethanolic extract. 


\section{MATERIALS AND METHODS}

\section{Collection of plant material}

The leaves of T. stans Juss (Bignoniaceae) grown in Iraq were collected from the area of University of Baghdad (Al-Jadria) in August and November 2003. The specimen was authenticated by Dr. Ali Al- Mousawi (University of Baghdad college of Science department of Biology) as shown in Figure 1. The leaves were dried at room temperature in the shade, pulverized by mechanical mills and weighed.

\section{Plant extraction procedure}

The dried leaves $(50 \mathrm{~g})$ were extracted by a Soxhlet apparatus using diethyl ether/ammonia (15\%) (90:10) as a solvent for $4 \mathrm{~h}$. The filtrate was in turn extracted with $4 \mathrm{~N}$ $\mathrm{HCl}$ at room temperature (step A). The organic phase was dried with anhydrous sodium sulphate and evaporated to dryness under reduced pressure to give a white precipitate. The precipitate was further purified by dissolving it in chloroform then precipitation by dropwise addition of methanol.

The acidic aqueous phase obtained in Step A was extracted with hexane (A) then ethyl acetate (B), and finally it was treated with ammonia until $\mathrm{pH} 12$ in order to obtain the alkaloidal fraction.

1. Hexane: The organic phase was then washed with water, treated with anhydrous sodium sulphate, and the solvent was removed under reduced pressure at $30^{\circ} \mathrm{C}$. The resultant white precipitate, consisting of sterols, was further investigated.

2. Then the aqueous phase from step (1) was extracted with ethyl acetate $(1: 3 \mathrm{v} / \mathrm{v})$ three times in order to obtain the phenolic and polyphenolic fraction.

3. The aqueous phase from step (2) was then extracted three times with diethyl ether $(1: 3 \mathrm{v} / \mathrm{v})$. The ethereal phase was then evaporated and a white precipitate was obtained.

The acidic aqueous phase was then treated with ammonia $(30 \%)$ until $\mathrm{pH} 12$ that was accompanied with a change in the color to a dark greenish brown, and introduced to a separatory funnel, where it was extracted with dichloromethane three times $(1: 3 \mathrm{v} / \mathrm{v})$. The organic layer was then dried with anhydrous sodium sulphate and the solvent was removed under reduced pressure at $40^{\circ} \mathrm{C}$ giving dark brown greenish crude alkaloidal fraction of approximately $4 \mathrm{~g}(7,11)$. This crude extract has been then used for the purification of Tecomine.

\section{Aqueous and ethanol extraction}

$50 \mathrm{~g}$ of the dried leaves were pulverized then soaked with



Figure 1: The aerial part of the plant Tecoma stans

each solvent separately for $72 \mathrm{~h}$ at $25^{\circ} \mathrm{C}$ with occasional stirring (protected from light). The extract was filtered and then the solvent was removed under reduced pressure to dryness by the rotary evaporator. The recovery weight was about $20-30 \%$ from the dried material. ${ }^{[12,13]}$

\section{Thin layer chromatography}

Precoated $20 \times 20 \mathrm{~cm}(0.25 \mathrm{~mm}$ thick) TLC Kieselgel GF254 plates (Merk) were activated at $110^{\circ} \mathrm{C}$ for $1 \mathrm{~h}$ before use for the analysis. Developing solvent system used $100 \mathrm{ml}$ placed in the glass Jar $(22.5 \mathrm{~cm} \times 22 \mathrm{~cm} \times 7 \mathrm{~cm})$ lined with Whatman no.1 filter paper (GE Healthcare) covered with a glass lid and allowed to saturate with appropriate mobile phase (saturation time $1 \mathrm{~h}$ ) before use. Different solvent systems were used for the separation of the alkaloidal fraction the one with the best separation Dichloromethane: methanol: ammonia (89.5: $10: 0.5 \mathrm{v} / \mathrm{v})$. Identification reagent for alkaloids was Dragendorff spraying reagent. The solvent system used for isolation of polyphenolic compounds with very good separation $n$-hexane : ethyl acetate : acetic acid $(62: 28: 10 \mathrm{v} / \mathrm{v})$, for detection UV light 254 and $366 \mathrm{~nm}$, standard reference compounds used were caffeic acid, ferulic acid quercetin, and catechin. The solvent system used for isolation and separation of phytosterols: toluene: ethyl acetate $(93: 7 \mathrm{v} / \mathrm{v})$, which gave the best separation, detection through vanillin/sulpheric acid (2\%), and standard reference compound used - sitosterol. ${ }^{[14,15]}$

\section{Column chromatography}

The column with a length of $(75 \mathrm{~cm} \times 20 \mathrm{~mm})$ was packed with (50 gm) silica gel (kicselgel 60) suspended in dichloromethane $(100 \mathrm{ml})$. The alkaloidal fraction $(1 \mathrm{~g})$ was dissolved in a minimum amount of dichloromethane and applied to the top of the column. Using gradient elution technique the mobile phase of dichloromethane and increasing quantity of methanol from $0-40 \%$. Equal 
volumes $(5 \mathrm{ml})$ of 70 fractions were collected and each fraction was evaporated from the solvent then monitored by TLC. Fractions that contain the same pure compound were mixed together, $0.1 \mathrm{~g}$ of tecomine was extracted. While the fraction which contains more than one alkaloid, further purified and isolated by preparative chromatography. ${ }^{[16]}$

\section{Preparative thin layer chromatography}

The fraction which contained more than one compound was dissolved in minimum quantity of dichloromethane and applied on a number of preparative precoated $20 \times 20 \mathrm{~cm}(2 \mathrm{~mm}$ thickness) TLC Kieselgel GF254 plates (Merck, Germany). With the solvent system dichloromethane: methanol: ammonia (89.5:10: $0.5 \mathrm{v} / \mathrm{v}$ ). Two major bands were observed by spraying side of the plate with Dragendorff spraying reagent to indicate the position of the bands. The two bands were scrapped, eluted with dichloromethane, and then filtered; the filtrate was evaporated to dryness under vacuum.

\section{Animals and Experimental design}

Eight-week old male BALB/c mice weighing (22 \pm 2 gm) from the University of Baghdad, college of science, department of biology. The mice were kept in metallic cages at a mean temperature of $23^{\circ} \mathrm{C}$ at a $12 \mathrm{~h}$ dark-light cycle and permitted to freely consume water and food in the animal house of research center of biotechnology Al-Nahrain University. All experiments were conducted between 10.00 and $17.00 \mathrm{~h}$ and were in accordance with the ethical guidelines of the International association for Study of Pain (Zimmerman 1983) and approved by the institutional animal ethics committee. The experimental design was performed by randomly dividing the 60 male mice into two main groups for each extract, and then six equal experimental groups (five mice per group) were used for these determinations. Ethanolic and aqueous extracts of $T$. stans previously prepared were used at concentrations of $0.0000625 \mathrm{~g} / 0.25 \mathrm{ml}(2.84 \mathrm{mg} / \mathrm{kg})$, $0.000625 \mathrm{~g} / 0.25 \mathrm{ml}(28.4 \mathrm{mg} / \mathrm{kg}), 0.00625 \mathrm{~g} / 0.25 \mathrm{ml}$ $(284 \mathrm{mg} / \mathrm{kg})$, and $0.0625 \mathrm{~g} / 0.25 \mathrm{ml}(2840 \mathrm{mg} / \mathrm{kg})$ for each group, respectively. Each group received the plant extract via oral gavage suspended in the phosphate buffer solution PBS for 15 consecutive days. While the control group received PBS only in a fixed volume of $1 \mathrm{ml} / 100 \mathrm{~g}$ body weight the sixth group received doxorubicin (DX) $10 \mathrm{mg} / \mathrm{kg}$ as positive control (sigma). Three independent experiments were performed. ${ }^{[17]}$ Animals were sacrificed by cervical dislocation with mid chloroform anesthesia. Blood was obtained via cardiac puncture, allowed to clot, centrifuged (1500 rpm, $10 \mathrm{~min}$, room temperature) and stored at $-20^{\circ} \mathrm{C}$ until analysis. The liver, spleen, and pancreas were excised from the mice and processed for histology assessment.

\section{Histopathology assessment of tissues}

Processing of tissue samples for histology assessment followed established procedures. In brief, the tissue samples were rinsed with $0.9 \%$ saline solution, fixed in $10 \%$ formalin. Then the diagonal section of the liver, the transverse section of the pancreas, and the horizontal section of the spleen were obtained and processed (Leica TP1020, Japan) as follows: (1) 10\% neutral buffered formalin for $1 \mathrm{~h}$, twice; (2) $70 \%$ alcohol for $1.5 \mathrm{~h}$; (3) $80 \%$ alcohol for $1.5 \mathrm{~h}$; (4) $90 \%$ alcohol for $1.5 \mathrm{~h}$; (5) absolute alcohol for $1.5 \mathrm{~h}$, twice; (6) xylene for $1.5 \mathrm{~h}$, twice; (7) in molten wax at $65^{\circ} \mathrm{C}$ for $2.5 \mathrm{~h}$ two changes. The processed tissues were embedded in paraffin and sectioned at $4 \mu \mathrm{m}$ thickness, placed on frosted glass slides and dried on a $70^{\circ} \mathrm{C}$ hot plate for $30 \mathrm{~min}$. The tissues were stained using the hematoxylin and eosin (HandE) stains. The sections were dewaxed in two changes of xylene ( 3 min each), hydrated in two changes of $100 \%$ ethanol, followed by $90 \%$ ethanol and $70 \%$ ethanol, for $3 \mathrm{~min}$ each, rinsed with water $(3 \mathrm{~min}$ ) and stained. The stained tissues were dehydrated with $70 \%$ ethanol followed by $90 \%$ ethanol, placed in two changes of $100 \%$ ethanol for 3 minutes each and cleaned with two changes of xylene ( 3 min each).

\section{Biochemical analysis}

Blood was obtained via cardiac puncture, allowed to clot, centrifuged (1500 rpm, $10 \mathrm{~min}$, room temperature) and stored at $-20^{\circ} \mathrm{C}$ until analysis. The biochemical estimation was done using the following methods serum glucose was measured by Medisense Optium glucometer. The glucose oxidase method was used to determine plasma glucose levels using a GM7 Analox glucose analyzer (Helena Laboratories, Mount Waverley, Victoria, Australia). Serum cholesterol (Parekh and junj.1970) and triglyceride (Rice 1970). The fast was performed overnight (18 h), with the food withdrawn at 4 pm. ${ }^{[18]}$

\section{Preparation of media and nutrient agar}

Media for assessing the antimicrobial activity was prepared by dissolving $8 \mathrm{~g}$ of nutrient broth (Merck, UK) in 11 of freshly distilled or completely demineralized water. Agar was prepared by dissolving $5 \mathrm{~g}$ of Bacto-agar (Difco laboratories, UK) in $200 \mathrm{ml}$ of distilled water with continuous stirring and heating until clear solution appears. Both the media and agar were sterilized by autoclaving at $121^{\circ} \mathrm{C}$ for $15 \mathrm{~min}$. Then they were left to cool down at $50-55^{\circ} \mathrm{C}$.

Bacteria used Staphylococcus aureus (ATCC 25923); Escherichia coli (ATCC 25922), and Bacillus subtilis (ATCC 6623) were supplied by Biotechnology Research Center, Al- Nahrain University, Iraq. The bacteria were grown in nutrient broth at $37^{\circ} \mathrm{C}$ and maintained on nutrient agar at $4^{\circ} \mathrm{C} .{ }^{[19]}$ 


\section{Determination of the antimicrobial activity}

Standard methods were used to determine minimum inhibitory concentration (MIC) and minimum bactericidal concentration (MBC) of the whole extracts and isolated tecomine. Strains were cultured overnight at $37^{\circ} \mathrm{C}$ in nutrient broth. Concentrations of the whole extracts and isolated tecomine were 25,50 , and $100 \mu \mathrm{g} / \mathrm{ml}$, respectively, in addition broth containing bacteria only without extract and broth containing the extract only without bacteria. The test was carried out by weighing 25, 50, and $100 \mu \mathrm{g} /$ $\mathrm{ml}$, respectively, of each extract dissolved or suspended in $1 \mathrm{ml}$ of the solvent. Sterile agar media weighing $99 \mathrm{ml}$ were added under aseptic conditions to $150 \mathrm{ml}$ flat bottom sterile Petri dishes together with $1 \mathrm{ml}$ of plant extract at different concentrations. These plates were allowed to solidify on a level surface. A loop full of inoculums suspensions (bacteria) was taken and streaked on a radial pattern on the agar containing the plant extract and isolated tecomine a triplicate agar plate were used in order to obtain accurate results, standard and control plates were treated in the same way without the plant extract (standard antibiotics were penicillin, vancomycin and cefotoxime). Results were taken from plates having the expected appearance of colonies otherwise the plates were discarded. Subcultures of these were used to determine MBC. Two susceptibility endpoints were recorded for each isolate. The MIC is defined as the lowest concentration of compounds at which the microorganisms tested did not demonstrate the visible growth. The MBC is defined as the lowest concentration yielding negative subculture or only one colony. ${ }^{[20,21]}$

\section{Determination of antimicrobial susceptibility using agar} well diffusion assay

Both extracts and isolated tecomine were tested for antimicrobial activity using the agar well diffusion method. Circular wells (6 $\mathrm{mm}$ in diameter) were cut in the agar culture media and filled with 25,50 , and $100 \mu \mathrm{L}$ extract. ${ }^{[2]}$

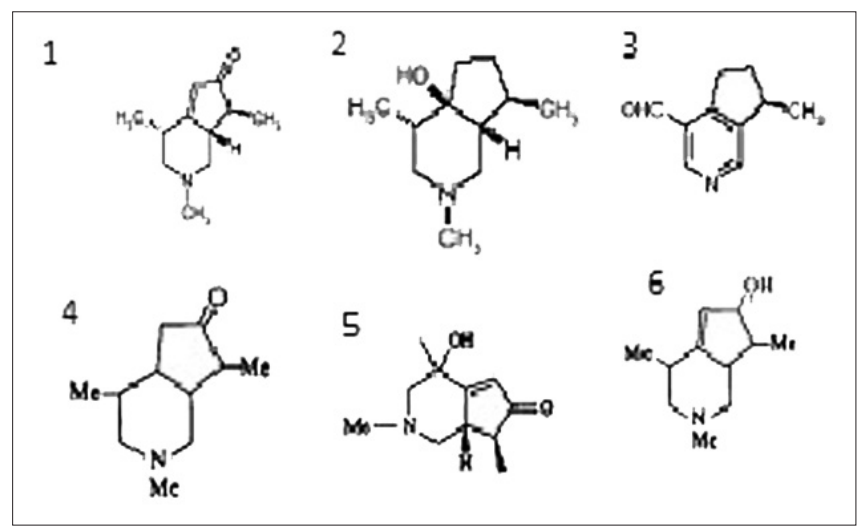

Figure 2: The structure of compounds isolated: 1-Tecomine, 2-5- $\beta$-Hydroxyskitanthine, 3- Boschniakine, 4- Dihydrotecomine, 5-4-Hydroxytecomine, 6-7-Hydroxyskitanthin

\section{Statistical analysis}

Analysis of data were performed by using SPSS (version 18). Results expressed as mean \pm S.D. statistical differences were determined by Student Newman Keul test for multiple comparison after ANOVA (Freund, 1981).

\section{RESULTS}

\section{Phytochemical results}

The alkaloidal fraction contained several alkaloids, as shown in Figure 2: boschniakine (0.9), tecomine (0.65), dihydro tecomine $(0.56)$, 4-hydrox tecomine $(0.5)$, 7-hydroxy skitanthine (0.4), and 5-hydroxy skitanthine (0.3), respectively, which were closely related to the authentic samples of the Egyptian and Brazilin T. stans provided by professor Luca Constantino. ${ }^{[7]}$ Preliminary detection of phytosterols (sitosterol) present in alcoholic, aqueous, and dichloromethane extracts of $T$. stans. Where the observed Rf values in all three samples were analogue to the standard Rf values 0.95. Preliminary detection of polyphenolic compounds present in the alcoholic, aqueous, and dichloromethane extracts of T. stans, as shown in Table 1.

\section{Spectroscopic analysis}

The identification of isolated compounds from the alkaloidal fraction were based on the comparison of spectral data with data reported in the literature. ${ }^{[4,6,7]}$ Tecomine (tecomanine) molecular formula of $\mathrm{C}_{11} \mathrm{H}_{17} \mathrm{NO}$ with molecular weight 179 yields $0.1 \mathrm{gm}$ as colorless oil, boiling point $125^{\circ} \mathrm{C}$, the UV absorption at $226 \mathrm{~nm}$. IR spectroscopy: $3053.11,1700,1595$, and $736 \mathrm{~cm}^{-1}$.

${ }^{1} \mathrm{H}-\mathrm{NMR}(\mathrm{CDCl}): 0.98$ (3H, d, J 6.8), 1.15 (3H, d, J 7.0), $1.3(2 \mathrm{H}, \mathrm{t}, \mathrm{J} 11.8), 1.9(3 \mathrm{H}, \mathrm{s}), 2.8(\mathrm{H}, \mathrm{m}), 3.2(1 \mathrm{H}, \mathrm{m})$, $3.3(3 \mathrm{H}, \mathrm{m}) .{ }^{13} \mathrm{C}-\mathrm{NMR} ; 11.52,19.0,29.8,32.0,33.8,36.6$, 50.9, 57.0, 146.2, 157.2, 181.0.

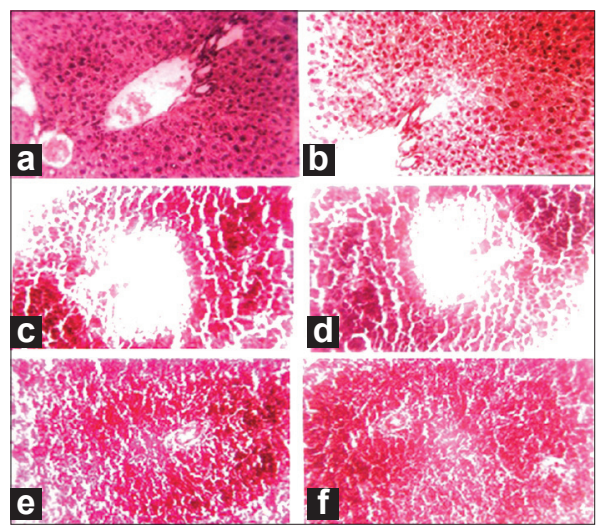

Figure 3: Sections for the liver, pancreas and spleen of the mice treated with the plant extract and control mice (not treated with plant extract), a. liver (control) b.Liver (extract) c. Pancreas (control) d. Pancreas (extract) e. Spleen (control) f. Spleen (extract) 


\begin{tabular}{|c|c|c|c|c|}
\hline \multicolumn{5}{|c|}{ Observed $R_{f}$ values } \\
\hline $\begin{array}{l}\text { Aqueous } \\
\text { extract }\end{array}$ & $\begin{array}{l}\text { ethanolic } \\
\text { extract }\end{array}$ & $\begin{array}{c}\text { Dichloromethane } \\
\text { extract }\end{array}$ & Stande & \\
\hline 0.78 & 0.78 & 0.93 & $\begin{array}{l}\text { Feruilic } \\
\text { acid }\end{array}$ & 0.78 \\
\hline 0.62 & 0.62 & - & $\begin{array}{l}\text { Caffeic } \\
\text { acid }\end{array}$ & 0.6 \\
\hline 0.4 & - & - & Quercetin & 0.4 \\
\hline 0.12 & 0.12 & 0.23 & Catechin & 0.12 \\
\hline
\end{tabular}

$\begin{aligned} & \text { Table 2: Change in the weights of the BALB/c } \\
& \text { mice treated by aqueous plant extract }\end{aligned}$
\begin{tabular}{lccc} 
Group & $\begin{array}{c}\text { Dose of the plant } \\
\text { extract }\end{array}$ & $\begin{array}{c}\text { Body weight } \\
\text { before the } \\
\text { application } \\
\text { of the extract }\end{array}$ & $\begin{array}{c}\text { Body weight } \\
\text { after the } \\
\text { application } \\
\text { of the } \\
\text { extract }\end{array}$ \\
\hline Group 1 & $0.0000625 \mathrm{~g} / 0.25 \mathrm{ml}$ & $22 \pm 2$ & $22 \pm 2$ \\
Group 2 & $0.000625 \mathrm{~g} / 0.25 \mathrm{ml}$ & $22 \pm 2$ & $20 \pm 2$ \\
Group 3 & $0.00625 \mathrm{~g} / 0.25 \mathrm{ml}$ & $22 \pm 2$ & $18 \pm 2^{*}$ \\
Group 4 & $0.0625 \mathrm{~g} / 0.25 \mathrm{ml}$ & $23 \pm 2$ & $15 \pm 2^{*}$ \\
Control & & $21 \pm 2$ & $22 \pm 2$ \\
DX & & $22 \pm 2$ & $12 \pm 2^{*}$ \\
\hline
\end{tabular}

Thirty male mice divided into six equal experimental groups (five mice per group); $\mathrm{DX}=$ Doxorubicin. *Statistically significant difference with respect to the result obtained in the negative control group. ANOVA and Student t-tests, $P \leq .05$.

\section{Body weight}

Body weight of group 3 and 4 given the ethanolic and aqueous extract of T. stans leaves showed significant effect on the body weight of treated mice as compared to control. As shown in Tables 2 and 3.

\section{Histopathological examination}

The macroscopic findings of the organs taken from the mice (liver, spleen, and pancreas) were normal in size and shape were only the liver of the mice treated with the plant extract of the highest dose was $1 / 2$ the weight of the normal or control mice and yellowish in color. While the microscopic examination of the control and the mice treated with plant extract, liver sections showed the intact liver architecture with normal hepatocyte, central vein, and portal tract (bile duct, portal vein, and hepatic artery). Pancreas section showed preserved pancreatic tissue normal exocrine (acinar cell) and endocrine (islet cells). Spleen section showed normal red and white pulps. There were no significant pathological lesions detected in the mice for the treated and control groups as shown in Figure 3. However, the group treated with DX showed significant change in the texture of the organs, liver and spleen hyperplasia, with degeneration of the pancreas. ${ }^{[18]}$

\section{Biochemical analysis}

The findings predict that the plant extract may have an
Table 3: Change in the weights of the BALB/C mice treated by alcoholic plant extract

\begin{tabular}{lccc}
\hline Group & $\begin{array}{c}\text { Dose of the plant } \\
\text { extract }\end{array}$ & $\begin{array}{c}\text { Body } \\
\text { weight } \\
\text { before the } \\
\text { application } \\
\text { of the } \\
\text { extract }\end{array}$ & $\begin{array}{c}\text { Body weight } \\
\text { after the } \\
\text { application } \\
\text { of the } \\
\text { extract }\end{array}$ \\
\hline Group 1 & $0.0000625 \mathrm{~g} / 0.25 \mathrm{ml}$ & $21 \pm 2$ & $21 \pm 2$ \\
Group 2 & $0.000625 \mathrm{~g} / 0.25 \mathrm{ml}$ & $23 \pm 2$ & $19 \pm 2$ \\
Group 3 & $0.00625 \mathrm{~g} / 0.25 \mathrm{ml}$ & $22 \pm 2$ & $17 \pm 2^{*}$ \\
Group 4 & $0.0625 \mathrm{~g} / 0.25 \mathrm{ml}$ & $22 \pm 2$ & $15 \pm 2^{*}$ \\
Control & & $21 \pm 2$ & $22 \pm 2$ \\
DX & & $23 \pm 2$ & $13 \pm 2^{*}$ \\
\hline
\end{tabular}

Thirty male mice divided into six equal experimental groups (five mice per group); $\mathrm{DX}=$ Doxorubicin. * Statistically significant difference with respect to the result obtained in the negative control group. ANOVA and Student $t$ tests, $P \leq .05$.

\begin{tabular}{|c|c|c|c|}
\hline Group & $\begin{array}{l}\text { FBS } \\
\text { mg/dl }\end{array}$ & $\begin{array}{c}\text { Cholesterol } \\
\mathrm{mg} / \mathrm{dl}\end{array}$ & $\begin{array}{c}\text { Triglyceride } \\
\text { mg/dl }\end{array}$ \\
\hline 1 & $135 \pm 3$ & $76 \pm 2$ & $132 \pm 1$ \\
\hline 2 & $100 \pm 2$ & $75 \pm 2$ & $130 \pm 1$ \\
\hline 3 & $95 \pm 2^{*}$ & $80 \pm 3$ & $135 \pm 2$ \\
\hline 4 & $64 \pm 3^{*}$ & $76 \pm 3$ & $133 \pm 2$ \\
\hline Control & $130 \pm 2$ & $75 \pm 2$ & $130 \pm 3$ \\
\hline$D X$ & $128 \pm 3$ & $78 \pm 1$ & $132 \pm 3$ \\
\hline
\end{tabular}

*Statistically significant difference with respect to the result obtained in the negative control group. ANOVA and Student t-tests, $P \leq .05$.

$\begin{aligned} & \text { Table 5: The effect of the alcoholic plant extract } \\
& \text { from Tecoma stans on biochemical parameters }\end{aligned}$
in the blood of the BALB/C mice
\begin{tabular}{lccc}
\hline Group & FBS & $\begin{array}{c}\text { Cholesterol } \\
\text { mg/dl }\end{array}$ & $\begin{array}{c}\text { Triglyceride } \\
\text { mg/dl }\end{array}$ \\
\hline 1 & $130 \pm 2$ & $78 \pm 2$ & $130 \pm 2$ \\
2 & $108 \pm 1$ & $73 \pm 1$ & $135 \pm 3$ \\
3 & $100 \pm 3^{*}$ & $78 \pm 2$ & $133 \pm 2$ \\
4 & $70 \pm 3^{*}$ & $77 \pm 2$ & $128 \pm 2$ \\
Control & $135 \pm 2$ & $73 \pm 3$ & $135 \pm 2$ \\
DX & $130 \pm 3$ & $79 \pm 1$ & $133 \pm 3$ \\
\hline
\end{tabular}

*Statistically significant difference with respect to the result obtained in the negative control group. ANOVA and Student t-tests, $P \leq .05$.

effect on the glucose level. As shown in Tables 4 and 5 .

\section{Microbiological study}

Different extract (aqueous, ethanolic and tecomine) of T. stans were obtained and minimum inhibitory concentration (MIC) and minimum bacteriocidal concentration (MBC) were determined and inhibition zone diameter (IZD) was evaluated $(25,50,100 \mu \mathrm{g} / \mathrm{ml})$.

The alcoholic extract possesses the antibacterial activity against some of the tested microorganism, where the 


\begin{tabular}{|c|c|c|c|c|}
\hline \multirow[t]{2}{*}{ Microorganism } & \multirow{2}{*}{$\begin{array}{c}\text { Reference } \\
\text { antibiotic }\end{array}$} & \multicolumn{3}{|c|}{$\mathrm{MIC}(\mathrm{MBC}) \mu \mathrm{g} / \mathrm{ml}$} \\
\hline & & Aqueous & Tecomine & Ethanol \\
\hline $\begin{array}{l}\text { Staphylococcus } \\
\text { aureus }\end{array}$ & a & ND & ND & ND \\
\hline Escherichia coli & $b$ & ND & 50 & ND \\
\hline Bacillus subtilis & c & ND & ND & 30 \\
\hline
\end{tabular}

A: penicillin $\mathrm{G} 5 \mu \mathrm{g} / \mathrm{ml}$, B: cefotaxim $10 \mu \mathrm{g} / \mathrm{ml}$, C: vancomycin $10 \mu \mathrm{g} / \mathrm{ml} .^{[20]}$

growth of E. coli and B. subtilis was inhibited at different concentration as shown in Tables 6 and 7.

The tecomine possessed also the antibacterial activity against some of the tested microorganisms. Where the growth of E. coli and B. subtilis was inhibited at different concentrations.

The aqueous extract possesses no antibacterial activity against the tested microorganism; this may be due to the low concentration of the active constituent.

\section{DISCUSSION}

The mobile phase used dichloromethane in the presence of a small amount of methanol and ammonia. Therefore, the nonpolar compounds will run with the mobile phase toward the solvent front and the polar compounds will be in the lower end of the plate. Boschniakine has the higher $\mathrm{R}_{\mathrm{f}}$ value due to its pyridine ring. Tecomine was second due to its piperidine ring and to the unsaturation in the five-member ring, also due to the carbonyl group. As for the saturated compounds it becomes more polar and the 4-hydroxytecomine is more polar than dihydrotecomine because of the hydroxyl group $(\mathrm{OH})$ at $\mathrm{C}_{4}$ so it has a smaller $\mathrm{R}_{\mathrm{f}}$ value. Skitanthines are polar compounds due to the hydroxyl group $(\mathrm{OH})$ and it shows a slow movement in the mobile phase and since the 7-Hydroxy skitanthine is slightly less polar than the others due to its molecular weight (unsaturation between C5 and C6) it will have an $\mathrm{R}_{\mathrm{f}}$ value higher than the other skitanthines.

Studies on the antibacterial activities of medicinal plants have clearly become a progressive trend using the different screening method. The preliminary presence of polyphenolic compounds together with phytosterols (sitosterol) in the aqueous and alcoholic extracts indicated for the first time with the Iraqi T. stans. There effect is strongly dependent on their structural characteristics, related to the number of $\mathrm{OH}$ ring substituents and in the length and/or degree of saturation of the carbon chain
Table 7: The effect of the plant extract on the growth of Bacteria

\begin{tabular}{lcccc}
\hline Microorganism & \multicolumn{3}{c}{ Inhibition zone diameter IZD } \\
\cline { 2 - 4 } & Concentration & Aqueous & Tecomine & Ethanol \\
\hline $\begin{array}{l}\text { Escherichia coli } \\
\text { Staphylococcus }\end{array}$ & $25 \mu \mathrm{g} / \mathrm{ml}$ & + & \\
$\begin{array}{l}\text { aureus } \\
\text { Bacillus subtilis }\end{array}$ & $50 \mu \mathrm{g} / \mathrm{ml}$ & - & - \\
$\begin{array}{l}\text { Escherichia coli } \\
\text { Staphylococcus }\end{array}$ & & - & - & + \\
$\begin{array}{l}\text { aureus } \\
\text { Bacillus subtilis }\end{array}$ & & & & + \\
$\begin{array}{l}\text { Escherichia coli } \\
\text { Staphylococcus } \\
\begin{array}{l}\text { aureus } \\
\text { Bacillus subtilis }\end{array}\end{array}$ & $100 \mu \mathrm{g} / \mathrm{ml}$ & & & ++ \\
\hline
\end{tabular}

+: $5 \mathrm{~mm}$ IZD, ++: 10 IZD, +++: 15 IZD.

between the phenyl and the terminal carboxylate groups, which are known to exhibit the antioxidant activity. Also, the conformational behavior is important in the cytotoxic activity. The $\beta$-sisterol has an antibacterial activity and has a role in the antibacterial effect of the plant extract on microorganism. The alkaloidal fraction tecomine possesses antibacterial activity against E. coli. The solvent used for control, alcoholic, and distilled water used did not show any activity. ${ }^{[33]}$

The significant decrease in the blood glucose depending on the dose or amount of extract given to the mice gives a clear indication of a potential hypoglycemic effect of the Iraqi $T$. stans due to the different secondary metabolites present in the extracts, where most of the literature concentrate on the alkaloid Tecomine to be the element responsible for the hypoglycemic effect. In reference to the previous information, we recommend further investigation into the isolation, characterization, and mechanism of other secondary metabolites such as polyphenolic and phytosterols compounds.

The cholesterol level and triglyceride was not affected depending on the dose or amount of extract given to the mice.

There is a clear indication that the whole aqueous and ethanolic extracts do not have histopathological effect on the organs of the mice tested indicating potential safety of the extracts, which will need further animal studies to confirm.

However, there is no clear evidence, we have, showing which compound is mainly responsible for the anti-bacterial activity and this is a matter of further investigation. 


\section{CONCLUSION}

T. stans cultivated in Iraq contains a number of alkaloids basically the same as that of Egyption and Brazilian Tecoma, which need future study for its individual antimicrobial effect. It also contains other constituents such as polyphenolic and phytosterols. The decrease in the blood glucose indicates the initial potential hypoglycemic effect of the T. stans that will need further animal and clinical trial in order to confirm the antidiabetic effect. In addition, the aqueous and alcoholic plant extracts show no histopathological effect on the organs liver, spleen, and pancreas of the mice tested.

\section{ACKNOWLEDGMENT}

I thank Prof. Alaa Abd Al Rasoul Dean College of Pharmacy, Baghdad University for his guidance and engorgement, also I thank Dr. Mohammed Al-Jumaily Al-Nahrain biotechnology research center Al-Nahrain University for his valuable assistance.

\section{REFERENCES}

1. Boorsma GE, Meded, Lands' Plantent 1897;18:39. See Wehmer C, Die Pflanzenstoffe 2, 1136, Edwards JW, Edwards Brothers, Inc. Ann Arbor, Michigan (1950).

2. Hammouda $Y$, Motawi MM. Principal alkaloid isolated from Tecoma stans (L.) H.B.K. (Bignonia stans L.), Bignoniaceae Egypt Pharm Bull 1959;41:73.

3. Jones $\mathrm{GH}$, Fales M, Wildman WC. The structure of tecomanine. Tetrahedron Lett 1963;6:397-400.

4. Dickinson EM, Jones G. Pyrindane alkaloids from Tecoma stans. Tetrahedron 1969;25:1523-9.

5. Satya PK, Vaidyanathan CS. Indolic compounds in the leaves of Tecoma stans. Phytochemistry 1984;8:1826-7.

6. Arlete PL, Joana DF. Monoterpene alkaloids from Tecoma stans. Phytochemistry 1993;3:876-8.

7. Costantino L, Laura R, Renato P, Tiziana B, Pompeo P, Fabio $\mathrm{G}$, et al. Isolation and pharmacological activities of the Tecoma stans alkaloids. II Farmaco 2003;9:781-5.

8. Marzouk M, Gamal-Eldeen A, Mohamed M, El-Sayed M. Antiproliferative and antioxidant constituents from Tecoma stans. Z Naturforsch C 2006;61:783-91.

9. Aguilar-Santamaría L, Ramírez G, Nicasio P, Alegría-Reyes C, Herrera-Arellano A. Antidiabetic activities of Tecoma stans (L.) Juss. ex Kunth. J Ethnopharmacol 2009;2:284-8.

10. Mathur N, Jain GC, Pandey G. Effect of Tecoma stans leaves on the reproductive system of male albino rats. Int $\mathrm{J}$ Pharmacol 2010;6:152-6.

11. Senthilkumar CS, Kumar MS, Pandian MR. In Vitro Antibacterial activity of crude leaf extracts from Tecoma stans (L) Juss. et Kunth, Coleus Forskohlii and Pogostemon Patchouli against human pathogenic bacteria. Int J PharmTech Res 2010;2: 438-42.

12. Tan ML, Sulaiman SF, Najimuddin N, Samian MR, Tengku TS. Methanolic extract of Pereskia bleo (Kunth) DC. (Cactaceae) induces apoptosis in breast carcinoma, T47-D cell line. J Ethnopharmacol 2005;96:287-94.

13. Costa-Lotufo LV, Khan MT, Ather A, Wilke DV, Jimenez PC, Pessoa C, et al. Studies of the anticancer potential of plants used in Bangladeshi folk medicine. J Ethnopharmacol 2005;99:21-30.

14. Medi-Ari M, Ivona J, Asja SB, Mornar A. Optimization of chromatographic conditions in thin layer chromatography of flavonoids and phenolic acids. Croat Chem Acta 2004;77:361-6.

15. Angel MD, Hanganu $O$, Neli K. Qualitative and quantitative determination of caffeic acid and chlorogenic acid from three chemovarieties of chrysanthemum balsamita L. Roum. Biotechnol Lett 2001;6:477-8.

16. Peter JH. Chroatography of the chromosome and flavinoide alkaloids. J Chromatogr 2002;967:75-84.

17. Paniagua-Pérez R, Madrigal-Bujaidar E, Reyes-Cadena S, Molina-Jasso D, Gallaga JP, Silva-Miranda A, et al. Genotoxic and cytotoxic studies of beta-sitosterol and pteropodine in mouse. J Biomed Biotechnol 2005;2005:242-7.

18. Lim AY, Segarra I, Chakravarthi S, Akram S, Judson JP. Histopathology and biochemistry analysis of the interaction between sunitinib and paracetamol in mice. BMC Pharmacol 2010;10:14.

19. Berrin O, Astanllkay MO, Tange T. Antibacterial and antifungal and antiviral activity of the lipophylic extracts of pistacia vera. Microbiol Res 2005;160:159-64.

20. Pessini GL, Dias Filho BP, Nakamura CV, Cortez DA. Antibacterial activity of extracts and neolignans from Piper regnellii (Miq.) C.DC. var. pallescenes (C. DC.), Yunck. Mem Inst Oswaldo Cruz 2003;98:1115-20.

21. Cutler RR, Wilson P. Antibacterial activity of a new, stable aqueous extract of allicin against methicillin- resistant Staphylococcus aureus. Br J Biomed Sci 2004;5:243-7.

22. Awad $A B$, Williams $H$, Fink $C S$. Phytosterols reduce in vitro metastatic ability of MDA-MB-231 human breast cancer cells. Nutr Cancer 2001;40:157-64.

23. Awad $A B$, Fink CS. Phytosterols as anticancer dietary components, evidence and mechanism of action. J Nutr 2000;130:2127-30.

Cite this article as: Al-Azzawi AM, Al-Khateeb E, Al-Sameraei K, Al-Juboori AG. Antibacterial activity and the histopathological study of crude extracts and isolated tecomine from Tecoma stans Bignoniaceae in Iraq. Phcog Res 2012;4:37-43.

Source of Support: Nil, Conflict of Interest: None declared. 